${ }^{2}$ Styles, T. J., J. Parasitol., 51, 650 (1965). ${ }^{10}$ Field, A. K., Tytell, A. A., Lampson, G. P., and Hilleman, M. R., Proc.

${ }^{11}$ Baron, S., and Buckler, C. E., Science, 141, 1061 (1963).

${ }^{12}$ Stinebring, W. R., and Youngner, J. S., Nature, 204, 712 (1964).

${ }^{13}$ Ho, M., Science, 146, 1472 (1964).

14 Stauber, L. A., Exp. Parasitol., 18, 1 (1966).

${ }^{15}$ Stauber, L. A., Rice Inst. Pamph., 45, 80 (1958).

${ }^{10}$ Martínez-Silva, R., Correa, A., Colon, J., and Chiriboga, J., Abst. Nineteenth Ann. Meeting of Tissue Culture Assoc. (San Juan, Puerto Rico, 1968)

${ }^{17}$ Braun, W., and Nakano, M., Proc. Soc. Exp. Biol. Med., 118, 701 (1965)

${ }^{18}$ Braun, W., Nakano, M., and Freedman, H., Fed. Proc., 25, 370 (1966).

${ }^{19}$ Braun, W., and Kessel, R. W. I., in Bacterial Endotoxins (edit. by Landy, M., and Braun, W.) (Rutgers Univ. Press, New Brunswick, 1964).

${ }^{20}$ Braun, W., and Nakano, M., Science, 15\%, 819 (1967).

${ }^{21}$ Ho, M., Postic, B., and Ke, Y. H., in Ciba Foundation Symposium on Interferon (cdit. by Wolstenholme, G. E. W., and $\mathrm{O}^{\prime}$ Connor, M.) (Churchill

${ }^{22}$ Kono, Y., and Ho, M., Virolcgy, 25, 162 (1965).

${ }^{23}$ Cremer, N., and Watson, D. W., Proc. Soc. Exp. Biol. Med., 95, 510 (1957)

\section{Induction of Resistance to Bacterial Infections of Mice with Poly I.poly C}

RECENT reports describe the protective action of polyinosinic-polycytidylic acid (poly I.poly C), an inducer of interferon, on non-viral diseases (refs. 1 and 2 and personal communication of P. Actor, D. Kunkel, M. Goore, S. Garg and J. Pagano). Poly I-poly C also accelerates homograft rejection ${ }^{3}$ and cnhances the immunological response of animals to injection with influonza vaceine ${ }^{4}$. Such activitios are reminiscent of those of classical endotoxin. Treatment of mice with either substance is capable of inducing tolerance to subsequent challenge with lethal doses of endotoxin or poly I.poly $\mathrm{C}^{5}$. Both substances have also been shown pyrogenic for the rabbit ${ }^{6}$ and both are abortifacient $t^{7,8}$.

Table 1. EFFECT OE POLY I'POLY C ON EXPERIMENTAL BACTERIAL INFECTIONS OF MICE Survivors/total

\begin{tabular}{|c|c|c|c|c|c|c|c|c|}
\hline \\
\hline $\begin{array}{c}\text { Poly T. } \\
\text { poly C } \\
(\mu \mathrm{g} / \\
\text { mouse })\end{array}$ & $\underset{\mathbf{c}}{\mathrm{E}} \underset{\mathbf{1}}{\mathrm{coli}}$ & $\begin{array}{c}E \\
\text { coli } \\
3\end{array}$ & $\begin{array}{c}\text { Klebsiella } \\
\text { preu- } \\
\text { moniae } \\
\text { Ad. }\end{array}$ & $\begin{array}{c}\text { Klebsiella } \\
\text { pneu- } \\
\text { moniae } \\
17\end{array}$ & $\begin{array}{c}\text { Pseudo- } \\
\text { monas } \\
\text { aeru- } \\
\text { ginosa }\end{array}$ & $\begin{array}{c}\text { Salmon- } \\
\text { ella } \\
\text { para- } \\
\text { typhi }\end{array}$ & $\begin{array}{c}\text { Staphylo- } \\
\text { coccus } \\
\text { aureus } \\
\text { Gray }\end{array}$ & $\begin{array}{c}\text { Strepto- } \\
\text { coccus } \\
\text { pyo- } \\
\text { genes } \mathrm{C}\end{array}$ \\
\hline $\begin{array}{l}1 \cdot 0 \\
0 \cdot 1 \\
0 \cdot 01 \\
0\end{array}$ & $\begin{array}{l}5 / 6 \\
3 / 6 \\
2 / 6 \\
0 / 6\end{array}$ & $\begin{array}{l}5 / 6 \\
4 / 6 \\
4 / 6 \\
0 / 6\end{array}$ & $\begin{array}{l}4 / 6 \\
2 / 6 \\
2 / 6 \\
0 / 6\end{array}$ & $\begin{array}{l}4 / 6 \\
3 / 6 \\
3 / 6 \\
0 / 6\end{array}$ & $\begin{array}{l}2 / 6 \\
0 / 6\end{array}$ & & & $\begin{array}{l}4 / 6 \\
4 / 6 \\
0 / 6\end{array}$ \\
\hline
\end{tabular}

Mice were challenged $24 \mathrm{~h}$ after intraperitoneal treatment with poly I roly c by intraperitoneal injection with sufficient bacteria $\left(10^{6}-10^{7}\right)$ to produce death in all control mice in 18-24 h. Mortality was recorded $48 \mathrm{~h}$ after challenge. The poly II.poly C used (P.T. Biochemicals, Milwaukee) was dissolved in physiological phosphate buffer at $p \mathbf{H} 7$.

The prophylactic treatment of mice with poly $\mathrm{I} \cdot$ poly $\mathrm{C}$ or Escherichia coli endotoxin before infection with several bacteria has been studied to determine whether the parallel between poly I.poly $\mathrm{C}$ and endotoxin extended even further. Regelson ${ }^{9}$ has reported that pyran protects mice from experimental cryptococeal and pneumococcal infection, and that poly $\mathrm{I}$-poly $\mathrm{C}$ also offered somo protection against pneumococcal infection. The results in Table 1 illustrate the protective effect of poly I-poly C against experimental infections in mice with both Gram-negative and Gram-positive bacteria. The mice were CF-1 males (supplied by Carworth Farms, New City, New York) weighing approximately $20 \mathrm{~g}$ each. The poly I.poly C protects tho mice at levels as low as $0.01 \mu \mathrm{g}$ and is also effective in preventing death in mice from challenge with Columbia SK virus.

Table 2 shows the results of an exporiment with $E$. coli endotoxin and poly I-poly $\mathrm{C}$ against two strains of $E$. coli. The poly I.poly $\mathrm{C}$ and endotoxin afford protection against two isolates of $E$. coli. A linear dose-response curve was not always observed with poly I-poly $\mathrm{C}$ and the reason for this is not clear.

To investigate the relationship between endotoxin protection and poly I.poly $\mathrm{C}$ protection, the influence of the duration of time between treatment and challenge was investigated. Table 3 shows the results of an experiment where the challenge was administered at $1,6,24,48$ and $72 \mathrm{~h}$ after poly I-poly $\mathrm{C}$ or endotoxin treatment. Treatment of mice with poly I.poly $\mathrm{C}$ as long as 48 or $72 \mathrm{~h}$ before a challenge with two isolates of $E$. coli offered protection. In this respect, poly I.poly $\mathrm{C}$ and endotoxin protection are similar.

Table 2. THE PROTECTIVE EFFECT OF POLY I-POLY C AND ENDOTOXIX

$\begin{array}{lccc} & \text { ON EXPERIMENTAL } E \text {. coli INFECTION } \\ \text { Substance } & \text { Dose/mousc } & \begin{array}{c}\text { Survivors/total after challenge with: } \\ \text { E. coli } 1\end{array} & \begin{array}{c}\text { E. coli } 3 \\ \text { Poly I.poly C }\end{array} \\ & 1 \cdot 0 \mu \mathrm{g} & 2 / 10 & 2 / 10 \\ \text { Endotoxin } & 0 \cdot 1 \mu \mathrm{g} & 4 / 10 & 6 / 10 \\ & 1 \cdot 0 \mu \mathrm{g} & 10 / 10 & 10 / 10 \\ \text { Saline } & 0 \cdot 1 \mu \mathrm{g} & 3 / 10 & 6 / 10 \\ \text { S } & - & 0 / 10 & 0 / 10\end{array}$

Poly I-poly $\mathrm{C}$ and endotoxin were injected intraperitoneally, $24 \mathrm{~h}$ before challenge. Mortality was recorded at $48 \mathrm{~h}$ post-challenge. The endotoxi was lipopolysaccharide W derived from $E$, coli 026 : B6 (Difco, Detroit).

Table 3. INFLUENCE OF TIME OF CIIALLENGE ON PROTECTIVE HFFECT OF POLY I.POIY C AND ENDOTOXIN

Substance Dose Time of E. coli Survivors/total

\begin{tabular}{|c|c|c|c|c|c|c|}
\hline \multirow{2}{*}{ Substance } & \multirow{2}{*}{$\begin{array}{c}\text { Dose } \\
(\mu \mathrm{g})\end{array}$} & \\
\hline & & 1 & 6 & 24 & 48 & 72 \\
\hline Poly I'poly C & $\begin{array}{l}1 \cdot 0 \\
0.1\end{array}$ & $\begin{array}{l}8 / 10 \\
1 / 10\end{array}$ & $\begin{array}{l}3 / 10 \\
4 / 10\end{array}$ & $\begin{array}{l}2 / 10 \\
4 / 10\end{array}$ & $\begin{array}{l}4 / 10 \\
3 / 10\end{array}$ & $\begin{array}{l}3 / \vec{\pi} \\
2 / 7\end{array}$ \\
\hline Endotoxin & $\begin{array}{l}1 \cdot 0 \\
0 \cdot 1\end{array}$ & $\begin{array}{l}3 / 10 \\
0 / 10\end{array}$ & $\begin{array}{l}6 / 10 \\
6 / 10\end{array}$ & $\begin{array}{r}10 / 10 \\
3 / 10\end{array}$ & $\begin{array}{l}9 / 10 \\
6 / 10\end{array}$ & $6 / 7$ \\
\hline \multirow[t]{2}{*}{ None } & - & $0 / 10$ & $0 / 10$ & $0 / 10$ & $0 / 10$ & $0 / \pi$ \\
\hline & & \multicolumn{5}{|c|}{ 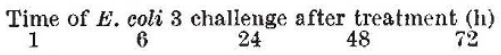 } \\
\hline Poly I-poly C & $\begin{array}{l}1 \cdot 0 \\
0 \cdot 1\end{array}$ & $\begin{array}{l}5 / 10 \\
4 / 10\end{array}$ & $\begin{array}{l}6 / 10 \\
7 / 10\end{array}$ & $\begin{array}{l}2 / 10 \\
6 / 10\end{array}$ & $\begin{array}{l}4 / 10 \\
2 / 10\end{array}$ & $\begin{array}{l}4 / 7 \\
3 / 7\end{array}$ \\
\hline Endotoxin & $\begin{array}{l}1 \cdot 0 \\
0 \cdot 1\end{array}$ & $\begin{array}{l}7 / 10 \\
5 / 10\end{array}$ & $\begin{array}{l}8 / 10 \\
8 / 10\end{array}$ & $\begin{array}{r}10 / 10 \\
6 / 10\end{array}$ & $\begin{array}{r}10 / 10 \\
7 / 10\end{array}$ & $6 / 7,7$ \\
\hline None & $\cdots$ & $0 / 10$ & $0 / 10$ & $0 / 10$ & $0 / 10$ & $0 / 7$ \\
\hline
\end{tabular}

In subsequent studies, mice injected intravenously with Newcastle disease virus (NDV) were bled $6 \mathrm{~h}$ after injection and the interferon-containing serum was given prophyl. actically to mice experimentally infected with $E$. coli. When mice were treated 1,3 or $6 \mathrm{~h}$ before challenge, no protection was observed. A single prophylactic administration of this serum protected mice from challenge with Columbia SK virus.

Although the resemblance between poly I.poly $\mathrm{C}$ and endotoxin has been widely documented, the protective activity of poly I.poly $\mathrm{C}$ against a variety of clinically isolated Gram-positive and Gram-negative bacteria has not been described. The mechanism by which it can protect mice infected with bacteria has not yet been examined, but the possibility that interferon per se is the protective factor is not favoured because interferoncontaining scrum administered to mice gave no protection. A more acceptable hypothesis is that poly I.poly C has a stimulating influence on a host non-specific resistance mechanism or reticuloendothelial system which affords protection against bacteria.
M. J. WEINSTEIN
J. A. WAIT'
P. F. CAME

Schering Corporation,

Bloomfield,

New Jersey.

Received Scptember 25; revised October 27, 1969.

' Jahiel, R. I., Vilček, J., Nussenzweig, R. G., and Vanderberg, J. Ścience, 161, $802(1968)$.

${ }^{2}$ Levy, H. B., Law, I. W., and Rabson, A. S., Proc. US Nat. Acad. Sci., 62. 357 (1969).

${ }^{3}$ Levy, H. B., $U S-J a p a n$ Seminar on Interferon (Tokyo, 1969).

${ }^{4}$ Woodhour, A. F., Friedman, A., Tytell, A. A., and Hilleman, M. R., Fior. Soc. Exp. Biol. and Med., 131, 809 (1969).

${ }^{5}$ Absher, M., and Stinebring, W. R., Nature, 223, 715 (1969).

- Lindsay, H. I., 'Trown, P. W., Brandt, J., and Forbes, M., Nature, 228, 717 $(196 \%)$.

7 Adamson, R. H, and Fabro, Sergio, Nature, 223, 718 (1969).

${ }^{8}$ Rieder, R. F., and Thomas, L., J. Immunol., 84, 189 (1960).

- Regelson, W., and Munson, A., Proc. Second Conference on Antiviral Sub. stances (New York Acad. Sci,, 1969). 